\title{
Extraction of extracellular polymeric substances from activated sludge using sodium oxalate
}

\author{
M. Sajjad ${ }^{1,2}$ - K. S. Kim ${ }^{1,2}$
}

Received: 22 September 2015/Revised: 18 February 2016/Accepted: 13 April 2016/Published online: 3 May 2016

(C) Islamic Azad University (IAU) 2016

\begin{abstract}
In this study, sodium oxalate was employed to extract extracellular polymeric substances (EPS) from activated sludge samples. The optimum dose of sodium oxalate was $1.34 \mathrm{~g} / \mathrm{g}$ VSS (volatile suspended solids), and the extraction time was $60 \mathrm{~min}$ at $\mathrm{pH}$ 7. The total EPS contents obtained under the optimized conditions were approximately $191 \mathrm{mg} / \mathrm{g}$ VSS, and they predominantly consisted of proteins, polysaccharides and humic substances. The extraction efficiencies of the chosen method for the major biopolymers were 39,43 and $410 \%$ higher compared with the ethylenediaminetetraacetic acid (EDTA), cation exchange resin and control methods. Cell lysis measured in terms of deoxyribonucleic acid, and unidentified EPS were approximately $50 \%$ lower in the sodium oxalate method than in the $\mathrm{NaOH}$ and EDTA methods. The EPS composition and the ratio of proteins/ polysaccharides (1.38-2.21) were extremely dependent on the operating conditions maintained during the extraction. The inductively coupled plasma spectroscopic results demonstrated that the release of divalent metals, such as $\mathrm{Ca}^{2+}$ and $\mathrm{Mg}^{2+}$, from the sludge matrix was directly correlated with higher EPS extraction efficiencies in the sodium oxalate protocol. Moreover, the precipitation of $\mathrm{Ca}^{2+}$ and $\mathrm{Mg}^{2+}$ as metallic oxalates disrupted the floc structure and subsequently enhanced the EPS recovery.
\end{abstract}

K. S. Kim

kskim@kict.re.kr

1 Korea University of Science and Technology, 217 Gajeongro, Yuseong-gu, Daejeon 305-350, Republic of Korea

2 Environmental Engineering Research Division, Korea Institute of Civil Engineering and Building Technology, 283 Goyangdae-ro, Ilsanseo-gu, Goyang-Si, Gyeonggi-Do 411-712, Republic of Korea
Fourier transform infrared studies revealed the presence of functional groups due to EPS molecules in all extracted samples.

Keywords Cation bridging - Fourier transform infrared characterization - Ion exchange - Process optimization . Quantification

\section{Introduction}

Extracellular polymeric substances (EPS) are high molecular weight organic compounds secreted by microorganisms into the environment (Sheng et al. 2010). EPS can be categorized as either soluble EPS (weakly attached) or bound EPS (strongly attached) depending on their binding strength with sludge flocs (Wingender et al. 1999; Liu and Fang 2003). The contents and compositions of EPS are very heterogeneous and mainly depend on food source, bioreactor operating parameters, ecosystem nature and wastewater type (Nielsen and Jahn 1999; Sponza 2003; Sheng et al. 2010). Proteins and polysaccharides are the predominant components of EPS and have been reported in almost all types of sludge samples (Frølund et al. 1996; Cescutti et al. 1999). Some studies have highlighted the presence of humic substances in substantial amounts as well as uronic acids and deoxyribonucleic acids (DNA) (Nielsen et al. 1996; Zhang et al. 1999). The presence of DNA is due to cell lysis, and high amounts of DNA reveal the harshness of the extraction process (Liu and Fang 2002).

EPS play a significant role in controlling sludge characteristics, such as surface charge, flocculation, settling, dewatering and removal of heavy metals during wastewater treatment (Morgan et al. 1990; Nielsen et al. 1996; 
Watanabe et al. 1999; Liao et al. 2001; Liu et al. 2001; Liu and Fang 2003; Merrylin et al. 2013; Zhu et al. 2014; Wang et al. 2015). EPS have been reported to increase floc size by binding to fine particles and bacterial cells, which eventually enhance sludge settleability (Watanabe et al. 1999; Liu and Fang 2003). The dewaterability of sludge strongly depends on the nature and amounts of EPS; usually, a high protein/polysaccharide (PN/PS) ratio effectively increases the water removal characteristics of sludge particles owing to the hydrophobic nature of EPS (Morgan et al. 1990; Bura et al. 1998; Liu and Fang 2003). Moreover, EPS have also shown tremendous potential toward the biosorption of heavy metals because of the presence of various functional groups (hydroxyl, carboxyl and amide) on their molecules (Liu et al. 2001; Joshi and Juwarkar 2009).

It is very important to obtain an accurate idea of the major EPS constituents in a sludge matrix to elucidate their exact role during wastewater treatment. Unfortunately, published results are contradictory, and replication of data is difficult because no standard extraction methods are available. Many physical and chemical methods have been proposed for EPS extraction (Sun et al. 2012). Common physical methods include centrifugation, ultrasonication and heating (Dignac et al. 1998; Liu and Fang 2002; Comte et al. 2006; Sun et al. 2012), while chemical methods for extracting sludge EPS are mainly $\mathrm{NaOH}$ (alkaline), ethylenediaminetetraacetic acid (EDTA) and cation exchange resin (CER) (Brown and Lester 1980; Frølund et al. 1996; Sheng et al. 2005). The disadvantages of physical methods include their low EPS yields and protein denaturation at high temperature. The use of chemical methods significantly increases extraction efficiency, but can also contaminate the collected EPS or cause problems in subsequent analysis stages. The $\mathrm{NaOH}$ method induces higher cell lysis and macromolecule disruption because of the high pH ( 10) conditions (Frølund et al. 1996; Sheng et al. 2010). The disadvantages of the EDTA method include interference of residual reagents with proteins during spectrophotometric determinations (Comte et al. 2006). CER has become the most widely used EPS extraction method because of its low cell lysis, and the resin can be removed by centrifugation, thus avoiding chemical pollution. However, the requirement of high reagent doses of approximately $75 \mathrm{~g}$ CER/g VSS and high stirring speeds (900 rpm) for long durations ( $3 \mathrm{~h}$ ) make it a very costly and time-consuming protocol; hence, the method is not very effective for routine estimation of EPS during the sludge treatment processes. Moreover, high stirring speeds for extended periods can cause cell lysis as well.

In the present study, a new EPS extraction method employing sodium oxalate as the extractant was proposed to overcome problems such as low yield, high extractant doses and comparatively long contact times associated with existing methods. This extraction procedure was based on the ion exchange mechanism. It is quite evident from the literature that the microbial biomass and EPS are attached with divalent metals through the formation of bridged complexes in activated sludge systems (Higgins and Novak 1997a, b). The main challenge to increase the extraction efficiency is to break up this bridged structure to subsequently release EPS. Sodium oxalate was selected because oxalate anions have a strong binding affinity with divalent cations, particularly $\mathrm{Ca}^{2+}$ and $\mathrm{Mg}^{2+}$, which will ease the removal of these metals from the sludge matrix and consequently help increase EPS extraction. Furthermore, the introduction of sodium $\left(\mathrm{Na}^{1+}\right)$ ions from the reagent into the sludge will enhance the ratio of monovalent/divalent cations, which will lead to displacement of divalent cations and disintegration of the floc structure, thereby increasing the extraction efficiency. The research work was carried out at the Environmental Engineering Research Division, Korea Institute of Civil Engineering and Building Technology (KICT), Ilsanseo-Gu, Goyang-Si, Gyeonggi-Do, Republic of Korea, during the year 2015.

\section{Materials and methods}

\section{Activated sludge samples}

The aerobic activated sludge was sampled from the aeration tank of a local wastewater treatment plant (Ilsan, South Korea). The sludge was allowed to settle, after which the supernatant was decanted. To remove the debris and other soluble matter, the sludge was washed with distilled water. The VSS contents of sludge were measured by following the standard methods (APHA 1998). The sludge samples were filtered through a Whatman filter paper (Grade GF/C: $1.2 \mu \mathrm{m}$ ), and the residue left on filter paper was dried at $103-105{ }^{\circ} \mathrm{C}$ for $2-3 \mathrm{~h}$ and termed as sludge suspended solids (SS). Then, the filter paper used for SS was ignited at $550{ }^{\circ} \mathrm{C}$ for $30 \mathrm{~min}$ in a muffle furnace along with a blank filter paper. The loss on ignition of solids represented the sludge VSS, and these were found about $5.0 \mathrm{~g} / \mathrm{L}$. Afterward, a specific volume of sludge having VSS $5.0 \mathrm{~g} / \mathrm{L}$ was concentrated by centrifugation at $5000 \times \mathrm{g}$ for $10 \mathrm{~min}$ at $4{ }^{\circ} \mathrm{C}$ using a GYROZEN 1580 MGR centrifugation machine to remove the soluble material and to get the required amount of sludge pellets for use in the individual extraction methods.

\section{EPS extraction}

First, the extraction doses of sodium oxalate for EPS removal were optimized using the batch method. In this 
regard, aqueous solutions of sodium oxalate of $0.025,0.05$, $0.075,0.10,0.125$ and $0.15 \mathrm{~N}$ were prepared by dissolving the desired amount of reagent (equivalent weight) in distilled water. A total of $100 \mathrm{~mL}$ of each solution was measured into different extraction flasks, and a certain amount of the sludge pellets $(0.50 \mathrm{~g}$ VSS) was added to each of the flasks. In this way, the extraction flasks containing $0.025,0.05,0.075,0.10,0.125$ and $0.15 \mathrm{~N}$ sodium oxalate corresponded to doses of $0.33,0.67,1.0,1.34,1.67$ and $2.01 \mathrm{~g}$ sodium oxalate/g VSS, respectively. The samples were stirred in a shaking incubator at $4{ }^{\circ} \mathrm{C}$ for $60 \mathrm{~min}$ at $100 \mathrm{rpm}$. The EPS extracted from the chemically treated sludge were then separated by high-speed centrifugation at $15,000 \times g$ for $20 \mathrm{~min}$ and at $10,000 \times g$ for $10 \mathrm{~min}$ at $4{ }^{\circ} \mathrm{C}$. Finally, the samples were filtered through $0.20-\mu \mathrm{m}$ filter paper, after which the filtrate was examined to quantify the individual EPS components. The extractions were conducted at a neutral $\mathrm{pH}$, and the $\mathrm{pH}$ values of the aforementioned solutions were between 7.0 and 7.5. The effects of contact time (30,60,90 and $120 \mathrm{~min})$ and stirring speed (50, 100, 150 and $200 \mathrm{rpm})$ on EPS yields at optimized doses were also studied.

The effectiveness of this developed protocol under the optimized conditions was compared by simultaneously extracting EPS using previous methods (CER, $\mathrm{NaOH}$ and EDTA). The extractant doses and other experimental conditions in these methods were adopted from the reported literature. The EPS extraction using CER was performed according to the method described by Frølund et al. (1996). Briefly, the thickened sludge pellets were resuspended in a phosphate buffer solution $\left(2 \mathrm{mM} \mathrm{Na}_{3} \mathrm{PO}_{4}\right.$, $9 \mathrm{mM} \mathrm{NaCl}$ and $1 \mathrm{mM} \mathrm{KCl}$ ) at $\mathrm{pH}$ 7. The CER dose (Dowex $50 \times 8,20-25$ mesh, $\mathrm{Na}^{1+}$ form; Fluka) was maintained at $75 \mathrm{~g} / \mathrm{g}$ VSS and was stirred for $3 \mathrm{~h}$ at $900 \mathrm{rpm}$ and $4{ }^{\circ} \mathrm{C}$. The CER was washed with buffer before applying to the extraction beaker. For $\mathrm{NaOH}$ extraction, the sludge samples were added to distilled water, and the $\mathrm{pH}$ was maintained at 10 using $1 \mathrm{M} \mathrm{NaOH}$. The extraction was conducted at $4{ }^{\circ} \mathrm{C}$ for $3 \mathrm{~h}$ (Liu and Fang 2002; Comte et al. 2006). For the EDTA experiment, the sludge was added to a $2 \%$ EDTA solution, and the extraction was performed for $3 \mathrm{~h}$ at $4{ }^{\circ} \mathrm{C}$ (Liu and Fang 2002; Comte et al. 2006). EPS were also extracted by a physical method that served as a "control method" (Liu and Fang 2002; Comte et al. 2006). The sludge pellets were added in distilled water and EPS extracted by high-speed centrifugation $15,000 \times g$ for $20 \mathrm{~min}$ and then at $10,000 \times g$ for $10 \mathrm{~min}$ at $4{ }^{\circ} \mathrm{C}$ without adding any chemical reagents. The EPS extracted from the chemically treated sludge were also centrifuged at $15,000 \times g$ for $20 \mathrm{~min}$ and at $10,000 \times g$ for $10 \mathrm{~min}$ at $4{ }^{\circ} \mathrm{C}$. Finally, all the samples were filtered through $0.20-\mu \mathrm{m}$ filter paper, and the filtrates were examined to measure the various EPS constituents.

\section{EPS analysis}

To determine the total amounts of the EPS, the extracted samples were lyophilized at $-60{ }^{\circ} \mathrm{C}$ for $24 \mathrm{~h}$ in a freeze dryer (OPERON, model FDU-8612). The lyophilized samples were then ignited at $550{ }^{\circ} \mathrm{C}$ for $30 \mathrm{~min}$ in a muffle furnace. The loss in weight of samples after ignition was due to organic polymers, and it represented the total EPS contents. The samples were ignited at high temperature to remove any interference in total EPS amounts due to inorganic species. The contents of proteins and humic substances of extracted samples were measured by the modified Lowery method, Frølund et al. (1995) using bovine serum albumin and humic acid as the standard solutions, respectively. Polysaccharides were estimated by the phenolsulfuric acid method of Dubois et al. (1956) using glucose as the standard solution. Uronic acids were determined by the m-hydroxydiphenyl sulfuric acid method of Blumenkrantz and Asboe-Hansen using glucuronic acid as the standard (Blumenkrantz and Asboe-Hansen 1973). The DNA content was measured with the diphenylamine colorimetric method (Sun et al. 1999) using E. coli DNA as the standard solution. All the chemicals used were of analytical grade.

\section{ICP and FTIR investigations of EPS}

The concentrations of $\mathrm{Mg}^{2+}, \mathrm{Ca}^{2+}$ and $\mathrm{Fe}^{3+}$ in the EPS extracts from the sodium oxalate method were measured using an inductively coupled plasma optical emission spectrometer (ICP-OEC) from Perkin-Elmer (model, Optima 7300 DV). The purpose was to determine the effect of sodium oxalate doses on the release of these metals from the sludge matrix. One blank and four calibration standard solutions of known metal concentrations were prepared by dissolving the salt of each metal in distilled water. The actual content of the respective metal was obtained from a working calibration curve generated by the standard samples. For the FTIR (Fourier transform infrared) studies, the EPS solutions were freeze-dried under vacuum at $-85^{\circ} \mathrm{C}$ for $24 \mathrm{~h}$ and mixed with $\mathrm{KBr}$ to make pellets. These pellets were then analyzed using an FTIR spectrophotometer from Perkin-Elmer to characterize various functional groups on the molecules. All of the spectra were acquired at $2.0 \mathrm{~cm}^{-1}$ resolution and in a scanning range from 500 to $4000 \mathrm{~cm}^{-1}$.

\section{Results and discussion}

\section{EPS extraction using sodium oxalate}

\section{Effect of sodium oxalate dose on EPS extraction}

Table 1 summarizes the amounts of total EPS and their individual constituents that were extracted with varying 
Table 1 Amounts of EPS per gram of activated sludge (mg/g VSS) at different dosages of sodium oxalate (g sodium oxalate/g VSS); contact time $1 \mathrm{~h}$, stirring speed $100 \mathrm{rpm}$

\begin{tabular}{lllllllrr}
\hline $\begin{array}{l}\text { Dosage of } \\
\text { sodium oxalate }\end{array}$ & $\begin{array}{l}\text { Protein } \\
\text { (PN) }\end{array}$ & $\begin{array}{l}\text { Polysaccharide } \\
\text { (PS) }\end{array}$ & $\begin{array}{l}\text { Humic } \\
\text { substance }\end{array}$ & $\begin{array}{l}\text { Uronic } \\
\text { acid }\end{array}$ & DNA & Unknown & \multicolumn{1}{c}{ Total EPS } & \multicolumn{1}{l}{$\begin{array}{l}\text { PN/PS } \\
\text { ratio }\end{array}$} \\
\hline 0.33 & $31.2 \pm 2.6$ & $22.6 \pm 1.6$ & $14.3 \pm 1.3$ & $4.2 \pm 0.2$ & $0.25 \pm 0.01$ & $10.3 \pm 1.5$ & $82.8 \pm 3.4$ & 1.38 \\
0.67 & $54.4 \pm 3.6$ & $40.4 \pm 1.8$ & $20.1 \pm 1.5$ & $5.5 \pm 0.4$ & $0.32 \pm 0.02$ & $12.2 \pm 1.0$ & $132.9 \pm 5.6$ & 1.35 \\
1.0 & $74.3 \pm 3.8$ & $47.1 \pm 2.1$ & $23.8 \pm 1.1$ & $6.0 \pm 0.4$ & $0.36 \pm 0.02$ & $15.6 \pm 1.4$ & $167.2 \pm 6.2$ & 1.58 \\
1.34 & $92.5 \pm 4.0$ & $48.4 \pm 2.4$ & $24.9 \pm 1.8$ & $7.9 \pm 0.3$ & $0.35 \pm 0.04$ & $17.3 \pm 1.9$ & $191.4 \pm 7.4$ & 1.91 \\
1.67 & $97.5 \pm 4.2$ & $46.3 \pm 1.9$ & $25.2 \pm 1.5$ & $7.3 \pm 0.2$ & $0.40 \pm 0.03$ & $20.5 \pm 2.1$ & $197.2 \pm 7.8$ & 2.10 \\
2.01 & $101.1 \pm 3.9$ & $45.7 \pm 2.0$ & $24.7 \pm 1.7$ & $7.8 \pm 0.3$ & $0.42 \pm 0.03$ & $22.6 \pm 2.4$ & $202.3 \pm 7.5$ & 2.21 \\
\hline
\end{tabular}

doses of sodium oxalate. The quantities of extracted EPS increased very sharply as the sodium oxalate doses increased from 0.33 to $1.34 \mathrm{~g} / \mathrm{g}$ VSS. Table 1 also indicates that further increasing the reagent concentrations did not result in any substantial increases in EPS contents, and the total EPS amounts were $202.3 \pm 7.5 \mathrm{mg} / \mathrm{g}$ VSS at a dose of $2.01 \mathrm{~g} / \mathrm{g}$ VSS compared with $191.4 \pm 7.4 \mathrm{mg} / \mathrm{g}$ VSS at a $1.34 \mathrm{~g} / \mathrm{g}$ VSS dose. This showed that the amount of EPS recovered at a $1.34 \mathrm{~g} / \mathrm{g}$ VSS dose was approximately $95 \%$ of the EPS collected at a $2.01 \mathrm{~g} / \mathrm{g}$ VSS dose, highlighting that enhancing the extractant amount by approximately $50 \%$ (from 1.34 to $2.01 \mathrm{~g} / \mathrm{g}$ VSS) only caused a $5 \%$ increase in the EPS concentration. Therefore, a $1.34 \mathrm{~g} / \mathrm{g}$ VSS dose was chosen as the optimal amount for EPS extraction from activated sludge samples.

The behaviors of various EPS components were quite different from each other (Table 1). Polysaccharides and humic substances were extracted rapidly, and 97.3 and $95.6 \%$ of their contents, respectively, were recovered at a dose of $1.0 \mathrm{~g} / \mathrm{g}$ VSS. However, protein extraction was comparatively slow, and $73.5 \%$ of the proteins were obtained using the same amount of reagent. This varied trend in the biopolymers may be due to the specific positions that they occupy in the sludge particles. Proteins are present in the inner parts of sludge particles, while polysaccharides exist on the outer parts (McSwain et al. 2005). Therefore, protein extraction was more difficult than polysaccharide extraction; thus, a comparatively high reagent quantity was needed to extract the former than the latter, which was in accordance with results reported elsewhere (Frølund et al. 1996; Sheng et al. 2005). The increase in protein contents with increase in sodium oxalate dosage may be due to the reason that the binding between negatively charged carboxylic groups of proteins and multivalent metals $\left(\mathrm{Ca}^{2+}\right.$ and $\mathrm{Mg}^{2+}$ ) was weakened under these conditions (ion exchange) which resulted toward the release of more protein molecules. However, beyond the optimal dose, no appreciable increase in these EPS components was observed. Uronic acids were obtained in very small amounts and were predominantly observed at approximately $7 \mathrm{mg} / \mathrm{g}$ VSS at all of the doses tested. The order of the ease of extraction in present study was polysaccharides $>$ humic substances $>$ proteins $>$ uronic acids. In this study, proteins (ranked first) and polysaccharides (second) along with humic substances constituted the major portion, while uronic acids constituted the minor fraction of the EPS molecules, which is similar to the results of previous studies (Frølund et al. 1996; Liu and Fang 2002). It is important to note that the quantity of unidentified EPS increased from 10.3 to $22.6 \mathrm{mg} / \mathrm{g}$ VSS as sodium oxalate increased from 0.33 to $2.01 \mathrm{~g} / \mathrm{g}$ VSS. This may have been because of the degradation/reduction in organic polymers, such as polysaccharides and humic substances, at high concentrations of oxalate ions. This was evidenced by noting the decrease in the amounts of these polymers at doses higher than the optimal amount (Table 1).

The extracted samples were also analyzed by ICP to note the amount of $\mathrm{Ca}^{2+}, \mathrm{Mg}^{2+}$ and $\mathrm{Fe}^{3+}$ released from the sludge matrix and to investigate the effects of these metals on EPS extraction (Fig. 1). Figure 1 indicates that the amounts of $\mathrm{Ca}^{2+}$ and $\mathrm{Mg}^{2+}$ recovered from the sludge

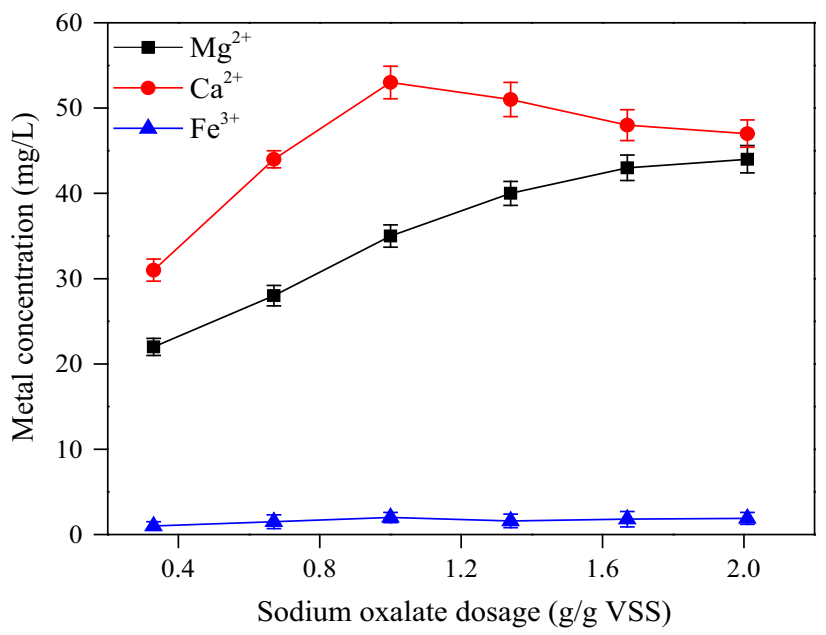

Fig. 1 Effect of sodium oxalate doses on the release of $\mathrm{Mg}^{2+}, \mathrm{Ca}^{2+}$ and $\mathrm{Fe}^{3+}(\mathrm{mg} / \mathrm{L})$ from the sludge matrix during EPS extraction (contact time $1 \mathrm{~h}$, stirring speed $100 \mathrm{rpm}$ ) 
samples initially increased by augmenting sodium oxalate. The release of divalent metals disintegrated the floc structure by breaking up the EPS-metal complexes, thereby enhancing EPS recovery. Bruus et al. (1992) found that approximately half of the total $\mathrm{Ca}^{2+}$ content was involved with EPS to maintain the three-dimensional floc texture, and adding $\mathrm{Na}^{1+}$ released $\mathrm{Ca}^{2+}$ and EPS by breaking up this structure. From a dose of $1.0 \mathrm{~g} / \mathrm{g}$ VSS and higher, the $\mathrm{Ca}^{2+}$ contents decreased slightly, while $\mathrm{Mg}^{2+}$ contents were observed at similar levels. Notably, even though $\mathrm{Ca}^{2+}$ removal was slightly lower in the subsequent experiment, EPS recovery still increased. This can be interpreted in terms of the stability constant $\left(\log \mathrm{K}_{1}\right)$ values, which are 3.0 and 2.55 for $\mathrm{Ca}^{2+}$ and $\mathrm{Mg}^{2+}$ chelate complexes with oxalate ions, respectively (Furia 1973). Therefore, a fraction of the $\mathrm{Ca}^{2+}$ ions may have been precipitated as calcium oxalate (due to its strong affinity with oxalate ions) in the sludge and were no longer available as part of the biofilm. Furthermore, the recovery of $\mathrm{Mg}^{2+}$ and proteins at high doses revealed that $\mathrm{Mg}^{2+}$ was preferably attached to the protein in the sludge matrix. This was identical to our previous results, which showed that $\mathrm{Mg}^{2+}$ is strongly bonded with the amide functional groups of proteins (Sajjad and Kim 2015). Other researchers have also noted the enhanced tendency of multivalent cations to bind with EPS proteins (Dignac et al. 1998). $\mathrm{Fe}^{3+}$ leakage was very low and not very effective for EPS extraction.

\section{Effect of contact time and stirring speed on EPS extraction}

Table 2 displays the contents of the EPS with respect to the reaction time (extraction kinetics). The results revealed that the majority of the EPS (approximately $79 \%$ ) were extracted within the first 30 min of adding sodium oxalate, and the entire extraction was completed within $1 \mathrm{~h}$. The data show that approximately 68,95 and $94 \%$ of proteins, polysaccharides and humic substances, respectively, were removed from the sludge after $30 \mathrm{~min}$. This again highlighted that protein extraction was more difficult than extraction of polysaccharides and humic substances, and approximately $60 \mathrm{~min}$ was required for the former to show a similar extraction efficiency as the latter. Dignac et al. (1998) also found that polysaccharides were not tightly bound with metallic cations; thus, polysaccharides were extracted very easily compared with proteins. The results shown in Table 2 indicate that long contact times had a negative effect on the extraction yields. After 90- and 120-min reaction times, the samples showed decreasing trends in the concentrations of the major components, whereas the unidentified EPS were enhanced from 17.3 (60 $\mathrm{min}$ ) to $30.2 \mathrm{mg} / \mathrm{g}$ VSS after $120 \mathrm{~min}$. This clearly demonstrated that an extended contact caused cell lysis and polymer degradation, which was further endorsed by observing the almost $100 \%$ increase in DNA contents after $2 \mathrm{~h}$ compared with a 1-h reaction time. Regarding the removal of divalent metals, Fig. 2 shows that $\mathrm{Ca}^{2+}$ and $\mathrm{Mg}^{2+}$ were rapidly exchanged at the beginning of the experiment, and their contents leveled off after $60 \mathrm{~min}$, whereas $\mathrm{Fe}^{3+}$ collection was negligible during the entire investigated period. Based on the EPS and metal removal data, a 60-min contact time was selected as the optimal reaction time for EPS extraction. The results at various stirring speeds (ranging from 50 to $200 \mathrm{rpm}$ ) indicated that the EPS extraction was not dependent on the stirring

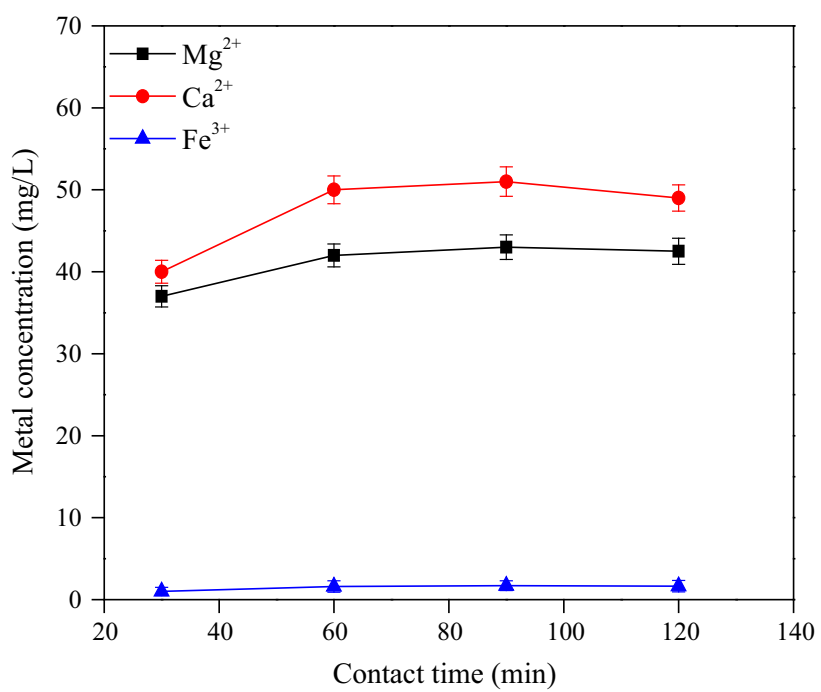

Fig. 2 Effects of extraction time (min) on the removal of $\mathrm{Mg}^{2+}$, $\mathrm{Ca}^{2+}$ and $\mathrm{Fe}^{3+}$ from activated sludge using sodium oxalate $(1.34 \mathrm{~g} / \mathrm{g}$ VSS) as the extractant (stirring speed $100 \mathrm{rpm}$ )

Table 2 Amounts of EPS per gram of activated sludge at different reaction times on optimal dosage of sodium oxalate (all values are in mg/g VSS, except PN/PS ratio)

\begin{tabular}{lllllllll}
\hline Extraction time $(\mathrm{min})$ & Protein & Polysaccharide & Humic substance & Uronic acid & DNA & Unknown & Total EPS & PN/PS ratio \\
\hline 30 & $63.2 \pm 3.5$ & $46.2 \pm 2.2$ & $23.5 \pm 1.2$ & $6.4 \pm 0.1$ & $0.28 \pm 0.03$ & $11.7 \pm 1.6$ & $151.3 \pm 5.6$ & 1.37 \\
60 & $92.5 \pm 4.0$ & $48.4 \pm 2.4$ & $24.9 \pm 1.8$ & $7.9 \pm 0.3$ & $0.35 \pm 0.04$ & $17.3 \pm 1.9$ & $191.4 \pm 7.4$ & 1.91 \\
90 & $87.7 \pm 4.5$ & $45.5 \pm 2.1$ & $22.6 \pm 1.6$ & $7.5 \pm 0.2$ & $0.50 \pm 0.05$ & $25.4 \pm 2.0$ & $189.2 \pm 7.8$ & 1.93 \\
120 & $85.3 \pm 3.8$ & $44.2 \pm 2.5$ & $21.5 \pm 1.4$ & $7.0 \pm 0.2$ & $0.71 \pm 0.06$ & $30.2 \pm 2.6$ & $188.9 \pm 8.2$ & 1.93 \\
\hline
\end{tabular}


intensity, and the EPS contents only varied from 3 to $5 \%$ at the examined speeds (results not shown).

\section{Comparison of the extraction efficiency of sodium oxalate with other methods}

Comparison of the EPS extraction efficiency of the sodium oxalate (optimal dose) method with $\mathrm{NaOH}$, EDTA, CER and control methods is given in Table 3. It is very evident from the results that all of the extraction methods led to very different EPS compositions and thus differences in their total contents. The $\mathrm{NaOH}$ and sodium oxalate methods extracted similar amounts of EPS, and their values were much higher than the other investigated techniques. The lowest amount of EPS was extracted by the control method. Overall, the order of EPS removal efficiency was $\mathrm{NaOH} \geq$ sodium oxalate $>$ EDTA $>$ CER $>$ control. The EPS contents indicate that, for each gram of volatile solids, the $\mathrm{NaOH}$ method extracted approximately $6 \mathrm{mg}$ more EPS than the sodium oxalate method. However, at the same time, the contribution of unidentified biopolymers in the EPS yield by the $\mathrm{NaOH}$ method was $20 \mathrm{mg}$ more than the oxalate method, which may be due to increased cell lysis in the $\mathrm{NaOH}$ protocol. Thus, if the EPS quantities of only three major biopolymers (protein + polysaccharide + humic substance) were taken into consideration, the sodium oxalate method outperformed all other methods employed during this study. In this case, the order of extraction was sodium oxalate $>\mathrm{NaOH}>$ EDTA $>$ CER $>$ control, and the extraction efficiency of the sodium oxalate procedure was 9, 39, 43 and $410 \%$ higher than the $\mathrm{NaOH}$, EDTA, CER and control methods, respectively.

Table 3 also compares the results of various EPS components extracted using different methods. Proteins were the predominant components of activated sludge and constituted approximately 48, 40, 31, 42 and $35 \%$ of the total EPS in the sodium oxalate, $\mathrm{NaOH}$, EDTA, CER and control methods, respectively, whereas the polysaccharides constituted 25, 22, 19, 28 and $27 \%$, respectively. The sum of the proteins and polysaccharides ranged from 50 to $70 \%$ of the total EPS obtained by different methods
(Sheng et al. 2010). The high protein contents in the sodium oxalate method showed that the method was very effective for EPS recovery from the inner parts of sludge particles because of the high binding affinity of oxalate for divalent metals, as discussed in "Effect of sodium oxalate dose on EPS extraction" section. The proteins and polysaccharides were placed first and second, respectively, among all of the extraction methods employed except for the EDTA protocol, in which humic substances were measured in higher amounts than polysaccharides. The quantities of unidentified EPS and DNA in the $\mathrm{NaOH}$ and EDTA extractions were the highest among all of the methods. The values of unidentified EPS and DNA in the $\mathrm{NaOH}$ extraction were 2.2 and 1.6 times higher than those obtained by the sodium oxalate method, respectively, while the same components measured by the EDTA method were approximately 1.9 and 1.8 times higher than the sodium oxalate procedure, respectively. The total amount of EPS extracted by the chemical methods constituted approximately $15-20 \%$ of the sludge volatile suspended solids, which was in good agreement with the findings of Urbain et al. (1993).

There are two main reasons for the high extraction efficiency of the sodium oxalate method. One explanation is that the oxalate ions formed a strong complex with the $\mathrm{Mg}^{2+}$ and $\mathrm{Ca}^{2+}$ ions in the activated sludge matrix (Furia 1973), thereby breaking the EPS-metal structure. The other possibility is that the sodium ions disrupted the floc structure and enhanced the metal exchange process, thereby increasing the EPS liberation rate. This was in agreement with previously published data that demonstrated that introducing sodium ions deteriorated the floc structure by displacing the $\mathrm{Mg}^{2+}$ and $\mathrm{Ca}^{2+}$ ions from the EPS complex, causing rapid recovery of the biopolymers (Higgins and Novak 1997a, b; Dignac et al. 1998). However, the high yield of the $\mathrm{NaOH}$ method was because of the increase in $\mathrm{pH}$, which led to the dissociation of the EPS functional groups and increased the water solubility of the EPS molecules (Comte et al. 2006).

The other advantages to using the sodium oxalate method are that it operates at a neutral $\mathrm{pH}$ (approximately

Table 3 Comparison of the amounts of EPS extracted from activated sludge using different methods (all EPS values are in mg/g VSS, except PN/PS ratio)

\begin{tabular}{|c|c|c|c|c|c|c|c|c|}
\hline Extraction method & Protein & Polysaccharide & $\begin{array}{l}\text { Humic } \\
\text { substance }\end{array}$ & $\begin{array}{l}\text { Uronic } \\
\text { acid }\end{array}$ & DNA & Unknown & Total EPS & $\begin{array}{l}\mathrm{PN} / \mathrm{PS} \\
\text { ratio }\end{array}$ \\
\hline $\begin{array}{l}\text { Sodium oxalate } \\
\quad \text { (optimal dosage) }\end{array}$ & $92.5 \pm 4.0$ & $48.4 \pm 2.4$ & $24.9 \pm 1.8$ & $7.9 \pm 0.3$ & $0.35 \pm 0.04$ & $17.3 \pm 1.9$ & $191.4 \pm 7.4$ & 1.91 \\
\hline $\mathrm{NaOH}$ & $79.1 \pm 3.6$ & $44.3 \pm 2.6$ & $28.6 \pm 1.7$ & $6.8 \pm 0.4$ & $0.56 \pm 0.05$ & $37.9 \pm 2.1$ & $197.3 \pm 7.1$ & 1.78 \\
\hline EDTA & $50.4 \pm 2.9$ & $31.1 \pm 2.2$ & $38.3 \pm 2.2$ & $8.3 \pm 0.4$ & $0.64 \pm 0.05$ & $32.7 \pm 2.2$ & $161.4 \pm 5.2$ & 1.62 \\
\hline CER & $57.8 \pm 2.5$ & $37.7 \pm 2.7$ & $20.1 \pm 1.9$ & $7.6 \pm 0.3$ & $0.27 \pm 0.02$ & $13.1 \pm 1.5$ & $136.6 \pm 4.8$ & 1.53 \\
\hline Control & $13.3 \pm 1.2$ & $10.4 \pm 1.1$ & $8.6 \pm 0.7$ & $1.9 \pm 0.2$ & $0.08 \pm 0.01$ & $3.8 \pm 0.3$ & $38.1 \pm 2.6$ & 1.28 \\
\hline
\end{tabular}


7.0) and also involves a very small amount of sodium oxalate; hence, there are relatively small chances of cell disruption and chemical pollution. The reagent (sodium oxalate) dose used in the sodium oxalate method was 56,3 and 1.5 times lower than that used in the $\mathrm{CER}, \mathrm{NaOH}$ and EDTA methods, respectively.

\section{PN/PS ratio}

The data shown in the last columns of Tables 1 and 2 indicate that during the sodium oxalate extraction, the EPS composition significantly varied as the reagent dose and reaction time changed, which consequently altered the sludge PN/PS ratios. These ratios were positively correlated with the amount of reagent and the contact time. The PN/PS ratio under the optimal conditions ( $1.34 \mathrm{~g} / \mathrm{g}$ VSS dose and 60-min reaction time) was approximately $40 \%$ higher than the $0.33 \mathrm{~g} / \mathrm{g}$ VSS dose and 30-min contact time. The lowest ratio was obtained at the beginning of the reaction due to the rapid recovery of polysaccharides, which are more prone to the extractant (Dignac et al. 1998).

The PN/PS ratios for the NaOH, EDTA, CER and control methods were $1.78,1.62,1.53$ and 1.28 , respectively, compared with 1.91 for the sodium oxalate method (Fig. 3). Observation of different PN/PS ratios for similar types of sludge samples revealed that the ratio strongly depended on how the extraction was accomplished, which clearly indicated the proper illustration of extraction conditions to report such results. However, all of the PN/PS values were in good agreement with the reported literature, in which they were found to be between 1.02 and 1.87 (Liu and Fang 2002), but were much lower than the findings reported by Frølund et al. (1996), who observed PN/PS ratios of approximately 5 . It is widely accepted that the sludge surface characteristics are largely controlled by the

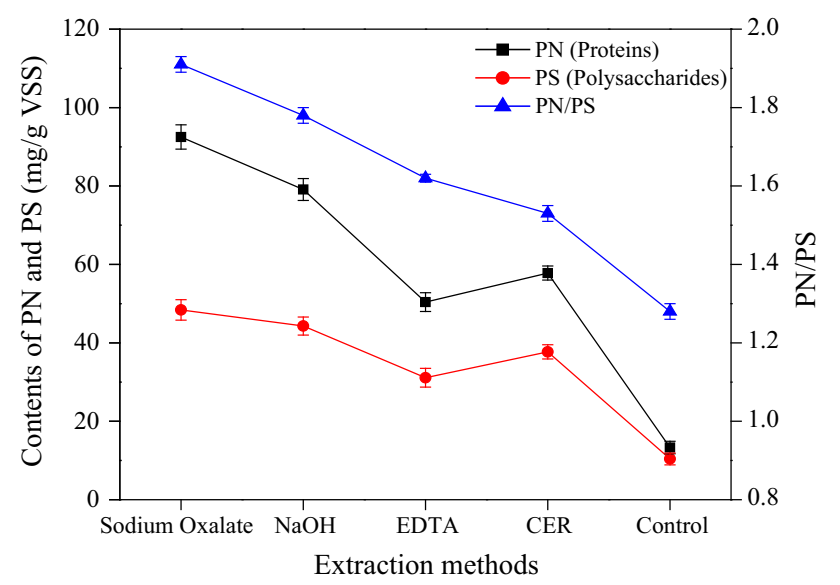

Fig. 3 Contents of protein, polysaccharide (mg/g VSS) and PN/PS ratio determined by different methods
PN/PS ratio, rather than the total EPS contents (Morgan et al. 1990). The high PN/PS ratio shows a positive correlation with the sludge dewaterability due to the hydrophobic nature of proteins (Morgan et al. 1990; Bura et al. 1998; Liao et al. 2001; Wang et al. 2015). The amino groups of proteins possess a positive charge; thus, the high PN/PS ratios effectively decreased the overall negative surface charge on the microbial cells, which is essential for sludge flocculation and in turn increases sludge settleability (Morgan et al. 1990; Liao et al. 2001). However, the biological treatment of wastewater is very complicated, and the nature of influent water along with sludge rheology should also be taken into consideration before assigning any features to the sludge flocs.

\section{FTIR characterization}

Figure 4 displays the IR spectra of the EPS extracted from activated sludge samples using different methods. From a qualitative point of view, the IR spectra were quite similar and showed the presence of several distinct and characteristic peaks because of the functional groups present in the EPS. Due to the complex compositions of EPS constituents and the presence of a large variety of functional groups on the EPS molecules, the exact characteristic absorption values are very difficult to determine in the IR spectra. The small shifts in the IR peak positions of the EPS samples may be due to the specific nature of the extracting agents used in the different protocols. The broad absorption band between 3200 and $3400 \mathrm{~cm}^{-1}$ in all of the

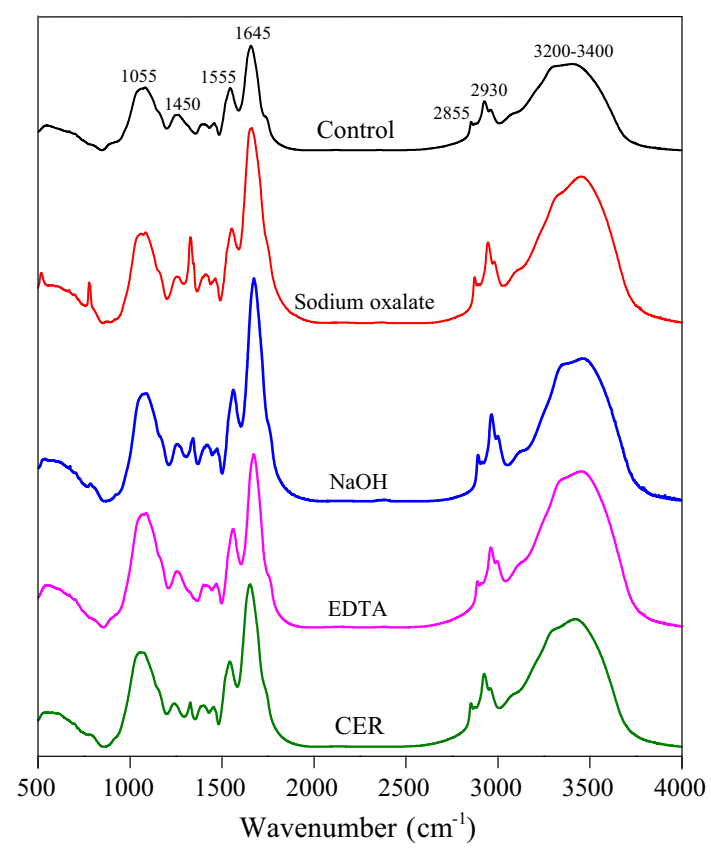

Fig. 4 FTIR spectra of EPS extracted using different methods 
spectra was assigned to the stretching vibrations of the $\mathrm{O}-$ $\mathrm{H}$ groups of polymeric compounds (Sheng et al. 2006; Tapia et al. 2009; Teh et al. 2014). The peaks from 2925-2935 and 2850-2860 $\mathrm{cm}^{-1}$, which are the result of asymmetric and symmetric stretching vibrations of $\mathrm{CH}_{2}$ groups, respectively, demonstrated the existence of aliphatic chains of polysaccharides, proteins and humic substances (Sheng et al. 2006; Shak and Wu 2014; Wang et al. 2014). Chai et al. 2007 reported that humic acids absorb light at wavelengths of 2930 and $1650 \mathrm{~cm}^{-1}$ (stretching vibrations of $\mathrm{C}=\mathrm{C}$ ). However, the IR identification of humic-like substances is very complicated because other organic groups also absorb in the same region. The absorption band between 1635 and $1655 \mathrm{~cm}^{-1}$ was associated with the stretching vibrations of $\mathrm{C}=\mathrm{O}$ and $\mathrm{C}-\mathrm{N}$ of amide I of the protein (Tapia et al. 2009; Sun et al. 2012; Bhatti and Hamid 2014). The peak from 1545 to $1565 \mathrm{~cm}^{-1}$ was assigned to the stretching vibration of $\mathrm{C}-\mathrm{N}$ and $\mathrm{N}-\mathrm{H}$ of amide II of the protein polymer (Tapia et al. 2009; Bhatti and Hamid 2014). The band from 1445 to 1455 was because of the deformation of the $\mathrm{CH}_{3}$ and $\mathrm{CH}_{2}$ groups of amide III. The peak at approximately $1420 \mathrm{~cm}^{-1}$ corresponded to the stretching vibrations of $\mathrm{C}=\mathrm{O}$ (carboxylates), which overlapped with amide III. The spectral band observed from 1035 to $1070 \mathrm{~cm}^{-1}$ (stretching vibration of $\mathrm{OH}$ ) was a characteristic absorption region of polysaccharides of EPS molecules (Omoike and Chorover 2004; Tapia et al. 2009; Sun et al. 2012). The small shoulder peak at approximately $1000 \mathrm{~cm}^{-1}$ was indicative of the phosphate group of nucleic acids. Overall, the IR data confirmed the presence of hydroxyl, amide, carboxyl and phosphate groups in all of the samples. From a quantitative point of view, the variations in peak heights/absorption intensities among different samples were correlated with the concentrations of their EPS components.

\section{Conclusion}

A new method using sodium oxalate as an EPS extractant was employed in this study. The extraction efficiency was evaluated at different reagent doses, reaction times and stirring intensities. A dose of $1.34 \mathrm{~g}$ sodium oxalate/g VSS and a contact time of $60 \mathrm{~min}$ at $100 \mathrm{rpm}$ were discovered as the optimal conditions for EPS extraction. The composition of EPS was found to be highly dependent on the extraction parameters. The total EPS content and the PN/ PS ratio under the optimized conditions were $191 \mathrm{mg} / \mathrm{g}$ VSS and 1.91, respectively. The extraction efficiencies of the sodium oxalate method were approximately 39, 43 and $410 \%$ higher than the commonly used EDTA, CER and physical methods, respectively. Cell lysis, measured as unidentified EPS and DNA contents, was approximately $50 \%$ lower than the $\mathrm{NaOH}$ and EDTA methods. The exchange of divalent metals $\left(\mathrm{Ca}^{2+}\right.$ and $\left.\mathrm{Mg}^{2+}\right)$ and the metal precipitation as oxalate chelates were found to be significantly involved in EPS extraction from activated sludge flocs. The FTIR spectra of EPS extracted using different protocols revealed the presence of hydroxyl, carboxyl, amide and phosphate functional groups of polysaccharides, proteins and humic substances. The high extraction efficiency of the sodium oxalate method, the requirements of minimal amount of sodium oxalate (approximately 56 times lower than the CER method), and the short reaction time at neutral $\mathrm{pH}$ make the sodium oxalate method a very useful alternative for EPS extraction from activated sludge particles.

Acknowledgments The authors are very thankful to Korea Institute of Civil Engineering and Building Technology, Korea University of Science and Technology (UST), Republic of Korea (Grant \# 2016-0158), for providing the financial support to complete this research work.

\section{Compliance with ethical standards}

Conflict of interest We confirm that the manuscript has been read and approved to submit it in the journal. It is confirmed that there is no conflict of interest in any matter regarding this research work and submission to the journal. It is also confirmed that the research work described in this manuscript has not been published previously and nor is being considered for publication elsewhere. Furthermore, if accepted, it will not be published elsewhere in any other journal or language and without the written consent of copyright holder.

$\begin{array}{ll}\text { Abbreviations } \\ \text { EPS } & \text { Extracellular polymeric substances } \\ \text { DNA } & \text { Deoxyribonucleic acids } \\ \text { EDTA } & \text { Ethylenediaminetetraacetic acid } \\ \text { CER } & \text { Cation exchange resin } \\ \text { PN/PS } & \text { Protein/polysaccharide } \\ \text { VSS } & \text { Volatile suspended solids } \\ \text { ICP } & \text { Inductively coupled plasma } \\ \text { FTIR } & \text { Fourier transform infrared }\end{array}$

\section{References}

APHA (1998) Standard methods for examination of water and wastewater, 20th edn. American Public Health Association, Washington

Bhatti HN, Hamid S (2014) Removal of uranium (VI) from aqueous solutions using Eucalyptus citriodora distillation sludge. Int $\mathbf{J}$ Environ Sci Technol 11:813-822

Blumenkrantz N, Asboe-Hansen G (1973) New method for quantitative determination of uronic acids. Anal Biochem 54:484-489

Brown MJ, Lester JN (1980) Comparison of bacterial extracellular polymer extraction methods. Appl Environ Microbiol 40:179-185 
Bruus JH, Nielsen PH, Keiding K (1992) On the stability of activated sludge flocs with implications to dewatering. Water Res 26:1597-1604

Bura R, Cheung M, Liao B, Finlayson J, Lee BC, Droppo IG, Leppard GG, Liss SN (1998) Composition of extracellular polymeric substances in the activated sludge floc matrix. Water Sci Technol 37:325-333

Cescutti P, Toffanin R, Pollesello P, Sutherland IW (1999) Structural determination of the acidic exopolysaccharide produced by a Pseudomonas sp. strain 1.15. Carbohydr Res 315:159-168

Chai X, Takayuki S, Cao X, Guo Q, Zhao Y (2007) Spectroscopic studies of the progress of humification processes in humic substances extracted from refuse in a landfill. Chemosphere 69:1446-1453

Comte S, Guibaud G, Baudu M (2006) Relations between extraction protocols for activated sludge extracellular polymeric substances (EPS) and EPS complexation properties. Part I. Comparison of the efficiency of eight EPS extraction methods. Enzyme Microb Technol 38:237-245

Dignac MF, Urbain V, Rybacki D, Bruchet A, Snidaro D, Scribe P (1998) Chemical description of extracellular polymers: implication on activated sludge floc structure. Water Sci Technol 38:45-53

Dubois M, Gilles KA, Hamilton JK, Rebers PA, Smith F (1956) Colorimetric method for determination of sugars and related substances. Anal Chem 28:350-356

Frølund B, Griebe T, Nielsen PH (1995) Enzymatic activity in the activated-sludge floc matrix. Appl Microbiol Biotechnol 43:755-761

Frølund B, Palmgren R, Keiding K, Nielsen PH (1996) Extraction of extracellular polymers from activated sludge using a cation exchange resin. Water Res 30:1749-1758

Furia TE (1973) CRC handbook of food additives, 2nd edn. CRC Press, Boca Raton

Higgins MJ, Novak JT (1997a) Characterization of exocellular protein and its role in bioflocculation. $J$ Environ Eng 123:479-485

Higgins MJ, Novak JT (1997b) The effect of cations on the settling and dewatering of activated sludges: laboratory results. Water Environ Res 69:215-224

Joshi PM, Juwarkar AA (2009) In vivo studies to elucidate the role of extracellular polymeric substances from Azotobacter in immobilization of heavy metals. Environ Sci Technol 43:5884-5889

Liao BQ, Allen DG, Droppo IG, Leppard GG, Liss SN (2001) Surface properties of sludge and their role in bioflocculation and settleability. Water Res 35:339-350

Liu H, Fang HHP (2002) Extraction of extracellular polymeric substances (EPS) of sludges. J Biotechnol 95:249-256

Liu Y, Fang HHP (2003) Influence of extracellular polymeric substances (EPS) on flocculation, settling, and dewatering of activated sludge. Crit Rev Environ Sci Technol 33:237-273

Liu Y, Lam MC, Fang HHP (2001) Adsorption of heavy metals by EPS of activated sludge. Water Sci Technol 43:59-66

McSwain BS, Irvine RL, Hausner M, Wilderer PA (2005) Composition and distribution of extracellular polymeric substances in aerobic flocs and granular sludge. Appl Environ Microbiol 71:1051-1057

Merrylin J, Kaliappan S, Kumar SA, Yeom IT, Rajesh BJ (2013) Effect of extracellular polymeric substances on sludge reduction potential of Bacillus licheniformis. Int J Environ Sci Technol 10:85-92

Morgan JW, Forster CF, Evison L (1990) A comparative study of the nature of biopolymers extracted from anaerobic and activated sludges. Water Res 24:743-750
Nielsen PH, Jahn A (1999) Extraction of EPS. In: Wingender J, Neu TR, Flemming HC (eds) Microbial extracellular polymeric substances: characterization, structure and function. Springer, Berlin, pp 49-72

Nielsen PH, Frolund B, Keiding K (1996) Changes in the composition of extracellular polymeric substances in activated sludge during anaerobic storage. Appl Microbiol Biotechnol 44:823-830

Omoike A, Chorover J (2004) Spectroscopic study of extracellular polymeric substances from Bacillus subtilis: aqueous chemistry and adsorption effects. Biomacromolecules 5:1219-1230

Sajjad M, Kim KS (2015) Studies on the interactions of $\mathrm{Ca}^{2+}$ and $\mathrm{Mg}^{2+}$ with EPS and their role in determining the physicochemical characteristics of granular sludges in SBR system. Process Biochem 50:966-972

Shak KPY, Wu TY (2014) Coagulation-flocculation treatment of high-strength agro-industrial wastewater using natural Cassia obtusifolia seed gum: treatment efficiencies and flocs characterization. Chem Eng J 256:293-305

Sheng GP, Yu HQ, Yu Z (2005) Extraction of extracellular polymeric substances from the photosynthetic bacterium Rhodopseudomonas acidophila. Appl Microbiol Biotechnol 67:125-130

Sheng GP, Yu HQ, Wang CM (2006) FTIR-spectral analysis of two photosynthetic $\mathrm{H}_{2}$-producing strains and their extracellular polymeric substances. Appl Microbiol Biotechnol 73:204-210

Sheng GP, Yu HQ, Li XY (2010) Extracellular polymeric substances (EPS) of microbial aggregates in biological wastewater treatment systems: a review. Biotechnol Adv 28:882-894

Sponza DT (2003) Investigation of extracellular polymer substances (EPS) and physicochemical properties of different activated sludge flocs under steady-state conditions. Enzyme Microb Technol 32:375-385

Sun Y, Clinkenbeard KD, Clarke C, Cudd L, Highlander SK, Dabo SM (1999) Pasteurella haemolytica leukotoxin induced apoptosis of bovine lymphocytes involves DNA fragmentation. Vet Microbiol 65:153-166

Sun M, Li WW, Mu ZX, Wang HL, Yu HQ, Li YY, Harada H (2012) Selection of effective methods for extracting extracellular polymeric substances (EPSs) from Bacillus megaterium TF10. Sep Purif Technol 95:216-221

Tapia JM, Munoz JA, Gonzalez F, Blazquez ML, Malki M, Ballester A (2009) Extraction of extracellular polymeric substances from the acidophilic bacterium Acidiphilium 3.2Sup (5). Water Sci Technol 59:1959-1967

Teh CY, Wu TY, Juan JC (2014) Potential use of rice starch in coagulation-flocculation process of agro-industrial wastewater: treatment performance and flocs characterization. Ecol Eng 71:509-519

Urbain V, Block JC, Manem J (1993) Bioflocculation in activated sludge: an analytic approach. Water Res 27:829-838

Wang Z, Gao M, Wang S, Xin Y, Ma D, She Z, Wang Z, Chang Q, Ren Y (2014) Effect of hexavalent chromium on extracellular polymeric substances of granular sludge from an aerobic granular sequencing batch reactor. Chem Eng J 251:165-174

Wang ZC, Gao MC, Ren Y, Wang Z, She ZL, Jin CJ, Chang QB, Sun CQ, Zhang J, Yang N (2015) Effect of hydraulic retention time on performance of an anoxic-aerobic sequencing batch reactor treating saline wastewater. Int $\mathrm{J}$ Environ Sci Technol 12:2043-2054

Watanabe M, Suzuki Y, Sasaki K, Nakashimada Y, Nishio N (1999) Flocculating property of extracellular polymeric substance derived from a marine photosynthetic bacterium, Rhodovulum sp. J Biosci Bioeng 87:625-629

Wingender J, Neu TR, Flemming HC (1999) What are bacterial extracellular polymeric substances? In: Wingender J, Neu TR, 
Flemming HC (eds) Microbial extracellular polymeric substances: characterization, structures and function. Springer, Berlin, pp 1-18

Zhang X, Bishop PL, Kinkle BK (1999) Comparison of extraction methods for quantifying extracellular polymers in biofilms. Water Sci Technol 39:211-218
Zhu L, Dai X, Xu X, Lv M, Cao D (2014) Microbial community analysis for aerobic granular sludge reactor treating high-level 4-chloroaniline wastewater. Int $\mathbf{J}$ Environ Sci Technol 11:1845-1854 